\title{
Recombinant human insulin-like growth factor I (rhIGF I) reduces hyperglycaemia in patients with extreme insulin resistance
}

\author{
E.J.Schoenle ${ }^{1}$, P.D.Zenobi ${ }^{2}$, T. Torresani ${ }^{1}$, E.A. Werder ${ }^{1}$, M. Zachmann' ${ }^{1}$ and E. R. Froesch ${ }^{2}$ \\ ${ }^{1}$ Department of Paediatrics and ${ }^{2}$ Department of Medicine, University of Zürich, Zürich, Switzerland
}

\begin{abstract}
Summary. The syndrome of type A insulin resistance is encountered in young women and is characterized by glucose intolerance or frank diabetes mellitus, endogenous hyperinsulinism, insensitivity to insulin administration, acanthosis nigricans and virilization. The insulin resistance is due to reduced cellular insulin binding because of a lack of or defective binding sites and/or because the interaction with the tyrosine kinase of the $\beta$-subunit is hindered. This study was undertaken to find out whether hyperglycaemia in these patients may be influenced by the administration of recombinant human insulin-like growth factor I which exerts insulinlike effects through the insulin receptor as well as the type 1 insulin-like growth factor I receptor. Recombinant human insulin-like growth factor I was intravenously administered in two subsequent doses of $100 \mu \mathrm{g} / \mathrm{kg}$ body weight to three women with type A insulin resistance. An immediate but
\end{abstract}

slow fall of blood glucose was observed. The glucose disappearance rate was $28.0 \mu \mathrm{mol} / \mathrm{min}$, i.e. considerably lower than that seen in healthy subjects. The markedly elevated insulin and C-peptide levels fell in a parallel manner to blood glucose but not to normal levels. The results show that recombinant human insulin-like growth factor I, presumably by reacting with the type 1 insulin-like growth factor receptor, can normalize serum glucose levels in patients with severe insulin resistance at least for several hours. We suggest that the potential of recombinant human insulin-like growth factor I to control hyperglycaemia in type A insulin resistant patients should be explored in more depth.

Key words: Type A insulin resistance, acanthosis nigricans, insulin-like growth factor I, insulin receptor, IGF I-administration.
The syndrome of type A insulin resistance is encountered in young women and characterized by glucose intolerance or frank diabetes mellitus, endogenous hyperinsulinism, insensitivity to insulin administration, acanthosis nigricans, hyperandrogenism, and virilization [1]. Cells from such patients exhibit markedly reduced insulin binding to the insulin receptor, suggesting a structural defect of the insulin receptor on the cell surface or a decreased receptor number [2,3]. Recently, the character of the defect has been elucidated by molecular investigations and structural alterations of the gene coding for the insulin receptor have been demonstrated. Point mutations or deletions located in certain parts of the $\alpha$-or $\beta$-subunit of the insulin receptor have been reported [4-8] which explain the markedly decreased insulin binding and/or the hindered interaction with the tyrosine kinase of the $\beta$-subunit. These discrete molecular alterations within the insulin receptor are responsible for the clinically observed insulin resistance and for the lack of an adequate response to insulin therapy.

The aim of the present study was to find out if it might be possible to help these patients by the administration of insulin-like growth factor I (IGF I), thus bypassing the defective insulin receptor system. IGF I is a peptide with structural homology to proinsulin [9]. Its biological effects have been extensively investigated [10]. IGF I exerts 1) rapid metabolic insulin-like effects in vitro and in vivo [10] and 2) slow growth-promoting effects in vivo $[11,12]$ which are believed to represent those that are physiologically ascribed to growth hormone and are mostly mediated through the IGF I/somatomedin axis [13].

When recombinant human IGF I (rhIGF I) became available recently for use in human subjects, Guler et al. $[14,15]$ demonstrated that its acute hypoglycaemic effects were similar to those of insulin and its potency was approximately $8 \%$ of that of insulin. Part of the hypoglycaemic effects of rhIGF I were ascribed to interaction with the insulin receptor. However, it had been shown earlier that IGF I influences glucose metabolism not only through the insulin receptor but also through the type 1 IGF receptor, mainly in muscle tissue $[16,17]$. In contrast to the insulin receptor, the type 1 IGF receptor appears to be intact in patients with type $\mathrm{A}$ insulin resistance justi- 


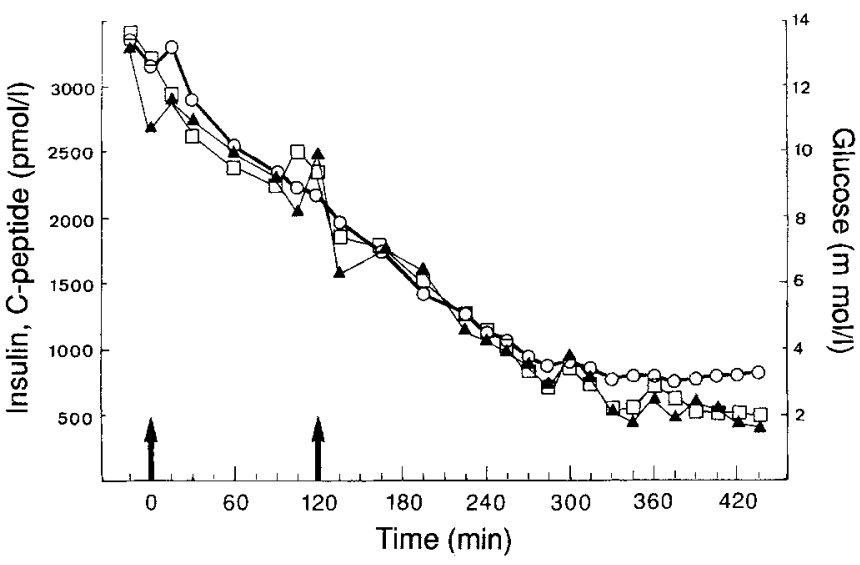

Fig. 1. Serum levels of glucose ( $O$ ), insulin ( $\Delta$ ) and C-peptide ( $\square$ ) in patient 1 with type $A$ insulin resistance after intravenous administration of recombinant human insulin-like growth factor I ([rhIGF I], $100 \mu \mathrm{g} / \mathrm{kg}$ body weight) at time $0 \mathrm{~min}(\uparrow)$ and $120 \mathrm{~min}(\uparrow)$

fying a short-term investigation with rhIGF I on metabolic glucose responses of such patients.

\section{Patients and methods}

Three women were studied, two with the typical clinical appearance of hyperandrogenism and acanthosis nigricans, the third - a sister of patient 2 - with milder virilization. All three have severe insulin resistance with high blood glucose levels, markedly elevated serum insulin concentrations, insensitivity to intravenously administered insulin and no evidence of insulin receptor antibodies. Therefore, after exclusion of the presence of insulin receptor antibodies, according to the literature, the patients were diagnosed as having type $\mathrm{A}$ insulin resistance. Insulin receptors in fresh cells were markedly reduced in two of the patients and they were not possible to study in patient 3 , a sister of patient 2 with comparable laboratory data. The gene for the insulin receptor from all three patients is being investigated at present. Informed consent was obtained from all three patients and/or their parents. The study was approved by the ethical committee of the Department of Paediatrics.

Case 1 is a 17-year-old girl of Spanish origin of normai weight with severe virilization and acanthosis nigricans. Impaired glucose tolerance with highly elevated insulin levels $(1750 \mathrm{pmol} / 1)$ in the fasting state had been diagnosed at age 6 . At the same age hirsutism and hypertrophy of the clitoris were recorded, whereas acanthosis nigricans on the neck and in the axilla was noted at the age of 9 years. At age 11, in an oral glucose tolerance test fasting glucose was nor$\mathrm{mal}(4.0 \mathrm{mmol} / \mathrm{l})$ with an approximately 100 times increased insulin (5200 pmol/l), which increased to a maximal level of $20,500 \mathrm{pmol} / \mathrm{l}$ at $90 \mathrm{~min}$ at a blood glucose level of $13.0 \mathrm{mmol} / \mathrm{l}$ at $120 \mathrm{~min}$. At age 12 fasting glucose was $9.3 \mathrm{mmol} / 1$ with an insulin level of $18,400 \mathrm{pmol} / 1$. During the last few years her diabetes deteriorated and the levels of blood glucose and glycosylated haemoglobin $\mathrm{A}_{1}\left(\mathrm{HbA}_{1}\right)$ were constantly elevated. $\mathrm{HbA}_{1}$ levels were between 11 and $12.5 \%$ (normal $<7.8 \%$ ). During an insulin tolerance test, intravenously administered short-acting insulin $(0.18 \mathrm{U} / \mathrm{kg}$ body weight $)$ did not show a significant effect on blood glucose levels. In an insulin receptor assay with rat fat cells using the patient's serum, there was no evidence for insulin receptor antibodies. In isolated fat cells from a small fat tissue biopsy of the inguinal subcutis from the patient specific binding of ${ }^{125}$ I-insulin was found to be very low $(0.5 \%$ compared to $1.4 \%$ in normal probands). However, for ethical reasons, these results, which fit the diagnosis of type $A$ insulin resistance, could not be verified by repeat assays (results not shown). The amenorrhoeic girl suffers psychologically from her quite apparent virilization (marked facial hir- sutism, increased body hair, deep voice, underdeveloped breasts, enlarged clitoris) resulting from markedly increased $(14.0 \mathrm{nmol} / \mathrm{l})$ serum testosterone levels.

Case 2 is a 29-year-old woman, a sister of case 3 , of Italian origin. She also suffers from insulin-resistance, marked virilization and acanthosis nigricans at the neck and in the axilla. Her clinical appearance as a teenager very much resembled that of case 1 . At age 16 (normal weight) an oral glucose tolerance test showed normal fasting glucose ( $4.2 \mathrm{mmol} / \mathrm{l})$ with highly elevated insulin $(1720 \mathrm{pmol} / \mathrm{l})$ followed by an impaired glucose tolerance: At $120 \mathrm{~min}$, glucose was $14.3 \mathrm{mmol} / \mathrm{l}$ with an insulin level of $9470 \mathrm{pmol} / \mathrm{l}$. This test has been repeated several times showing qualitatively and quantitatively similar results. On several occasions intravenously administered insulin $(0.15 \mathrm{U} / \mathrm{kg}$ body weight $)$ had no significant effect on blood glucose levels. However, despite abnormal glucose tolerance, insulinresistance was clinically less severe and blood glucose levels could be kept close to normal by a diet restricted in carbohydrates, as shown by $\mathrm{HbA}_{1}$ levels never exceeding $9 \%$ (normal $<7.8 \%$ ). There was no evidence for insulin receptor antibodies in the patient's serum in an assay with IM-9 lymphocytes. It was not possible to demonstrate insulin receptor binding on leucocytes from the patient (results not shown). The serum testosterone was elevated $(5.6 \mathrm{nmol} / \mathrm{l})$.

Case 3 is a 41-year-old sister of case 2, in whom virilization with primary amenorrhoea and diabetes mellitus (resistant to exogenous insulin) was diagnosed at the age of 19 years. Acanthosis nigricans was less striking in this patient than in her sister. This patient was slightly obese. In an earlier insulin tolerance test performed in another hospital it was not possible to induce hypoglycaemia. After a wedge resection of the ovary, this patient gave birth to two normal children. No further data with respect to glucose tolerance and insulin resistance from this patient are available. Her actual serum testosterone was elevated $(4.3 \mathrm{nmol} / \mathrm{l})$.

The patients were submitted to a tolerance test with rhIGF I after an overnight fast. They were asked to eat their regular amount of carbohydrates as prescribed in their dietary regimens before the test. Recombinant hIGF I was dissolved in $\mathrm{NaCl}(9 \mathrm{~g} / \mathrm{l})$ and two boluses, each of $100 \mu \mathrm{g} / \mathrm{kg}$ body weight were intravenously injected at 0 and $120 \mathrm{~min}$. Blood samples were taken at 5 -min intervals for the first $30 \mathrm{~min}$, and at longer intervals later on. During the $7 \mathrm{~h}$ (patients 2 and 3 ) or $8 \mathrm{~h}$ (patient 1 ) of the trial, the patients remained resting and continued to fast. Bedside blood glucose control was performed using commercial glucose test strips. After the test, the patients were asked to eat a carbohydrate rich meal. In one patient (case 1), an i.v. glucose infusion ( $25 \mathrm{~g}$ glucose within $15 \mathrm{~min}$ ) was given because blood glucose levels had fallen close to the hypoglycaemic range during the last $2 \mathrm{~h}$ of the trial

Recombinant hIGF I was kindly provided by Ciba-Geigy, (Basel, Switzerland). Insulin, C-peptide, growth hormone and testosterone were measured in duplicate using commercial radioimmu-

Table 1. Comparison of serum glucose, insulin, C-peptide, growth hormone (HGH) and insulin-like growth factor (IGF) I and II at 0 , 120,240 and 360 min in three patients with type $A$ insulin resistance after intravenous administration of recombinant human IGF I $(100 \mu \mathrm{g} / \mathrm{kg}$ body weight) at time 0 and $120 \mathrm{~min}$

\begin{tabular}{|c|c|c|c|c|c|c|c|}
\hline Patient & $\begin{array}{l}\text { Time } \\
\text { (min) }\end{array}$ & $\begin{array}{l}\text { Glucose } \\
(\mathrm{mmol} / \mathrm{l})\end{array}$ & $\begin{array}{l}\text { Insulin } \\
\text { (pmol/ })\end{array}$ & $\begin{array}{l}\text { C-peptide } \\
\text { (pmol/l) }\end{array}$ & $\begin{array}{l}\mathrm{HGH} \\
(\mathrm{mU} / \mathrm{l})\end{array}$ & $\begin{array}{l}\text { IGF I } \\
(\mathrm{ng} / \mathrm{ml})\end{array}$ & $\begin{array}{l}\text { IGF II } \\
(\mathrm{ng} / \mathrm{ml})\end{array}$ \\
\hline \multirow[t]{4}{*}{1} & 0 & 12.6 & 2680 & 3208 & 20 & 235 & 487 \\
\hline & 120 & 8.7 & 2480 & 2360 & $<1$ & 478 & 376 \\
\hline & 240 & 4.5 & 1075 & 1100 & $<1$ & 628 & 273 \\
\hline & 360 & 3.2 & 618 & 724 & $<1$ & 694 & 292 \\
\hline \multirow[t]{4}{*}{2} & 0 & 11.5 & 630 & 1226 & 3 & 179 & 733 \\
\hline & 120 & 7.2 & 395 & 784 & 7 & 408 & 566 \\
\hline & 240 & 5.0 & 196 & 416 & $<1$ & 639 & 558 \\
\hline & 360 & 5.5 & 250 & 478 & 1 & 785 & 661 \\
\hline \multirow[t]{4}{*}{3} & 0 & 11.3 & 605 & 1075 & 1 & 157 & 654 \\
\hline & 120 & 6.6 & 405 & 475 & $<1$ & 382 & 589 \\
\hline & 240 & 5.0 & 234 & 223 & $<1$ & 672 & 567 \\
\hline & 360 & 5.4 & 238 & 254 & $<1$ & 728 & 585 \\
\hline
\end{tabular}




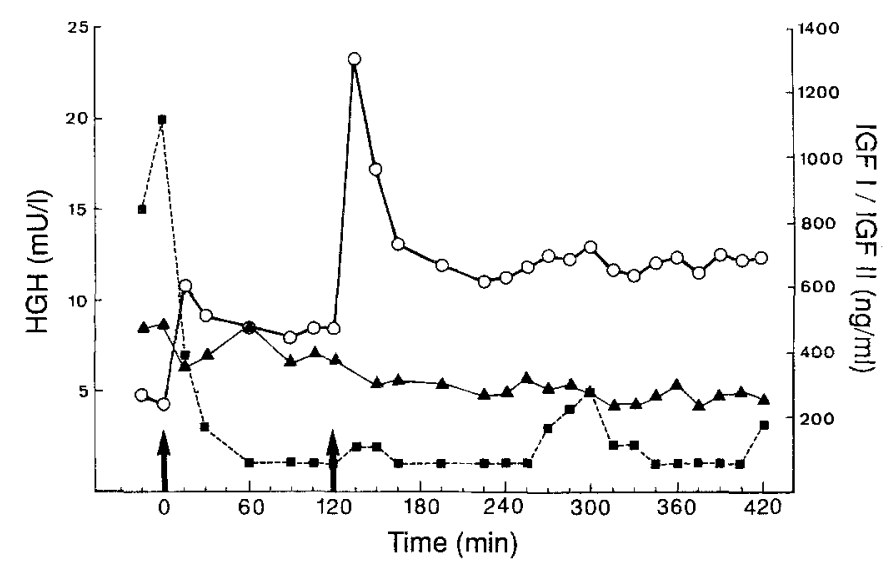

Fig. 2. Serum levels of insulin-like growth factor (IGF) I (O), IGF II (A) and growth hormone $(\mathrm{HGH})(\boldsymbol{\square})$ in patient 1 with type A insulin resistance after intravenous administration of recombinant human IGF I (100 $\mu \mathrm{g} / \mathrm{kg}$ body weight) at time 0 min ( $\uparrow)$ and $120 \min (\uparrow)$

noassay kits. Blood glucose was determined by glucose analyser. IGF I and IGF II were determined by radioimmunoassay after extraction of the serum in $1 \mathrm{~mol} / \mathrm{l}$ acetic acid as described previously [18]. The analysis of IGF binding proteins by ligand blotting was performed as described [19].

\section{Results}

Figure 1 shows glucose, insulin and C-peptide levels after i. v. administration of rhIGF I in patient 1. Fasting glucose levels were markedly elevated but started to fall shortly after the i.v. injection of rhIGF I and tended to level off in a still supranormal range after $2 \mathrm{~h}$. A second bolus of $100 \mu \mathrm{g} / \mathrm{kg}$ body weight of rhIGF I was injected, which was followed by a further fall of blood glucose into the normal range. As shown in Table 1 the glucose kinetics after rhIGF I administration were similar in all three patients, but not identical. The half-maximal decrease of blood glucose in patient 1 was reached after $135 \mathrm{~min}$ and after $45 \mathrm{~min}$ and $60 \mathrm{~min}$ in patients 2 and 3 , respectively. The initial glucose disappearance rate was similar in all three patients during the first $2 \mathrm{~h}$, namely $38.3 \pm 1.4 \mu \mathrm{mol} / \mathrm{min}$ (mean $\pm \mathrm{SD}$ ). The overall velocity of glucose disappearance (fasting minus minimal steady-state glucose concentration) was $28.0 \pm 2.9 \mu \mathrm{mol} / \mathrm{min}$ (mean $\pm \mathrm{SD}$ ). In healthy adults the blood glucose levels dropped from 4.65 to $1.98 \mathrm{mmol} / \mathrm{l}$ within $25 \mathrm{~min}$ after the administration of $100 \mu \mathrm{g}$ rhIGF I per $\mathrm{kg}$ body weight [14]. The velocity of glucose disappearance in healthy adults was $106.8 \mu \mathrm{mol} / \mathrm{min}$, i.e. considerably greater than in our three patients with type A insulin resistance.

The markedly elevated insulin and C-peptide levels started to fall in all three patients soon after the administration of rhIGF I. The fasting insulin and C-peptide levels differed markedly. Patient 1 had clearly higher levels than the two sisters in whom insulin and C-peptide levels were almost identical. In all three patients, insulin levels remained high relative to the glycaemia even when glucose concentrations had fallen into the normal (patients 2 and 3) or even low normal range (patient 1). Serum levels of C-peptide and of insulin declined in a parallel manner. However, the ratio of C-peptide to insulin levels was conspicuously low at all times in all three patients. As shown in Figure 1, the serum C-peptide and insulin concentrations were equimolar, the ratio being $1.0 \pm 0.1$ (mean \pm SD) in patient 1 throughout the trial. In patient 2 and 3 this ratio was $1.9 \pm 0.1$ and $1.7 \pm 0.1$, respectively.

Figure 2 shows serum concentrations of growth hormone, IGF I and IGF II in patient 1. After the first bolus of rhIGF I, the serum concentrations of IGF I rose from 251 to 468 and to $670 \mathrm{ng} / \mathrm{ml}$ after the second injection. The IGF I level remained almost constant until the end of the trial. The levels of IGF II which binds to the same serum binding proteins as IGF I decreased slowly from 480 to $256 \mathrm{ng} / \mathrm{ml}$. The concentration of the IGF binding protein3 did not change significantly during the test (results not shown).

The serum levels of growth hormone, IGF I and IGF II of all patients are compared in Table 1. IGF I levels increased two-fold and three-fold respectively after the first and second bolus of rhIGF I. The IGF II concentrations decreased to about two thirds of initial levels towards the end of the tests.

\section{Discussion}

Patients with type $\mathrm{A}$ insulin resistance exhibit elevated plasma glucose and markedly increased insulin levels. Insulin administration even at extremely high doses has little or no effect on blood glucose levels [1]. Deletions or point mutations in the insulin receptor gene have been demonstrated in several patients [4-8]. Therefore, either insulin binding to its receptor is hampered because of a lack of or defective binding sites and/or the interaction with the tyrosine kinase of the $\beta$-subunit is hindered [4-8].

Our study demonstrates that hyperglycaemia due to insulin resistance can be corrected, at least for some hours, by the administration of rhIGF I. In all three patients we studied, intravenous boluses of rhIGF I were capable of normalizing plasma glucose levels. However, there are striking differences in the reaction of our patients with insulin resistance to rhIGF I and the corresponding reaction of healthy subjects: intravenous administration of a bolus of rhIGF I to healthy adults is followed by an immediate and sharp drop of blood glucose levels identical to that observed after an $i$. v. bolus of insulin [14]. In contrast, our patients with insulin resistance react to rhIGF I with a slow decline of glycaemia. The glucose disappearance rate was three times slower than in healthy subjects.

The following might explain the different responses. After i.v. administration of an rhIGF I bolus, the concentration of free IGF I is acutely and markedly increased [14]. At these high concentrations of free IGF I in serum, this peptide crossreacts with the insulin receptor and exerts insulin-like effects on different cells and organs. Under these conditions, IGF I can mimic insulin in healthy subjects [14]. However, in patients with type A insulin resistance, transmission of the IGF I signal through the insulin receptor is impossible because of the molecular 
defect of the insulin receptor or the decreased number of receptors. Therefore, IGF I exerts its insulin-like action in insulin resistance most likely through the type 1 IGF receptor. This is supported by in vitro studies which show that insulin-like effects of IGFs can be mediated by the insulin-receptor as well as the type 1 IGF receptor. This is especially true for striated muscle $[12,20]$, a tissue which accounts for a large part of the entire glucose homeostasis in the body. The striking difference in glucose kinetics after IGF I administration between healthy subjects and patients with type A insulin resistance may be explained by the fact that in healthy subjects both insulin and type 1 IGF receptors in muscle and maybe also in other tissues function as IGF signal transducers.

Normally, IGF I and IGF II are bound to various serum binding proteins, mainly IGF binding protein-3, and only approximately $5 \%$ circulate in the free form [19]. It is believed that IGFs once they are bound to one of the binding proteins do not react with the insulin receptor and, therefore, cannot exert insulin-like effects through this receptor $[12,21]$. The short-term correction of hyperglycaemia in all three of our patients by the administration of IGF I was followed by a decrease of insulin and C-peptide levels. However, insulin and C-peptide levels remained elevated even when hypoglycaemia (patient 1) or normoglycaemia (patients 2 and 3) was reached. It would appear that the markedly increased insulin secretion in these patients might, as a consequence of the long-standing hyperglycaemia and resulting Beta-cell hypertrophy and hyperplasia, not be shut off immediately as in normal subjects when hypoglycaemia is reached.

As shown in Figure 1 (patient 1), insulin and C-peptide circulate in plasma in an equimolar ratio throughout the test. This is in striking contrast to normal subjects in whom the molar ratio between plasma levels of C-peptide and insulin is 5 to 8 in the fasted state $[22,23]$, because the halflife of the C-peptide is much longer than that of insulin. It has been demonstrated that between 50 and $70 \%$ of the pancreatic insulin is removed from the portal circulation during the first passage through the liver by way of receptor binding, immediate degradation and subsequent excretion of the degradation products $[24,25]$. Unlike insulin, C-peptide is mainly excreted by the kidney. The fact that the ratio between serum C-peptide and insulin was between 1 and 2 in all three patients indicates that both insulin and C-peptide are eliminated by similar mechanisms in these patients and suggests that it cannot be degraded by the liver because of the defective hepatic insulin receptor. As a result the half-life of insulin is prolonged, which also might be a contribution to the elevated insulin levels at the end of the test.

In contrast to the stimulation of grow th hormone secretion by acute hypoglycaemia due to IGF I (or insulin), prolonged intravenous administration of rhIGF I leads to a suppression of growth hormone secretion [26]. Our data support the notion of a negative feedback mechanism between IGF I and growth hormone secretion.

More or less increased serum testosterone levels accompanied by varying degrees of virilization are constant findings in type A insulin resistance with acanthosis nigricans. However, virilization is not specific for this syn- drome, since it is also found in other conditions with insulin resistance [27]. It is not yet clear if hyperandrogenism is secondary to elevated insulin levels. The testosterone levels were extremely high in patient 1 and mildly elevated in patients 2 and 3 .

In conclusion, our study demonstrates that it is possible to normalize hyperglycaemia in patients with severe insulin resistance - at least for several hours - by the administration of rhIGF I. In these patients with defective insulin receptors and hyperinsulinaemia, IGF I is likely to act through the type 1 IGF receptor in striated muscle and possibly in other tissues as well. Our results confirm and support the concept [28] that rhIGF I may be a useful therapeutic tool not only in type A insulin-resistant diabetic patients but also in other clinical conditions characterized by less marked insulin resistance such as Type 2 (non-insulin-dependent) diabetes mellitus, obesity and hypertriglyceridaemia.

Acknowledgements. We thank Prof. A. Prader and Prof. A. Fanconi for helpful discussions, and Ms. C. Waechter, Ms. J.Schuler, Dr. S.Jaeggi, and Ms. S. Graf for technical assistance. Supported by grants (No.32-29863.90 [Department of Paediatrics] and No.31-9095.87 [Department of Medicine]) from the Swiss National Science Foundation.

\section{References}

1. Kahn CR, Flier JS, Bar RS et al. (1976) The syndromes of insulin resistance and acanthosis nigricans. Insulin receptor disorders in man. N Engl J Med 294: 739-745

2. Kahn CR, Podskalny JM (1980) Demonstration of a primary (genetic?) defect in insulin receptors in fibroblasts from a patient with the syndrome of extreme insulin resistance. J Clin Endocrinol Metab 50: 1139-1141

3. Hedo JA, Moncada VY, Taylor SI (1985) Insulin receptor biosynthesis in cultured lymphocytes from insulin resistant patients. $\mathrm{J}$ Clin Invest 76: 2355-2361

4. Moller DE, Flier JF (1988) Detection of an alteration in the insulin-receptor gene in a patient with insulin resistance, acanthosis nigricans and the polycystic ovary syndrome (Type $A$ insulin resistance). N Engl J Med 319: 1526-1529

5. Yoshimasa Y, Seino S, Whittaker J et al. (1988) Insulin-resistant diabetes due to a point mutation that prevents insulin proreceptor processing. Science $240: 784-787$

6. Taira M, Taira M, Hashimoto N et al. (1989) Human diabetes associated with a deletion of the tyrosine kinase domain of the insulin receptor. Science 245: 63-66

7. Odawara M, Kadowaki T, Yamamota R et al. (1989) Human diabetes associated with a mutation in the tyrosine kinase domain of the insulin receptor. Science 245: $66-68$

8. Kadowaki T, Kadowaki H, Rechler MM etal. (1990) Five mutant alleles of the insulin receptor gene in patients with genetic forms of insulin resistance. J Clin Invest 86: 254-264

9. Rinderknecht E, Humbel RE (1978) The amino acid sequence of human insulin-like growth factor I and its structural homology with proinsulin. J Biol Chem 253:2769-2776

10. Zapf J, Schoenle E, Froesch ER (1978) Insulin-like growth factor I and II: Some biological actions and receptor binding characteristics of two purified constituents of nonsuppressible insulinlike activity of human serum. Eur J Biochem 87: 285-296

11. Schoenle E, Zapf J, Humbel RE, Froesch ER (1982) Insulin-like growth factor I stimulates growth in hypophysectomized rats. Nature 296: 252-253

12. Froesch ER, Schmid C, Schwander J, Zapf J (1985) Actions of insulin-like growth factors. Ann Rev Physiol 47: $443-467$ 
13. Salmon WD, Daughaday WH (1957) A hormonally controlled serum factor which stimulates sulfate incorporation by cartilage in vitro. J Lab Clin Med 49: 825-836

14. Guler HP, Zapf J, Froesch ER (1987) Short-term metabolic effects of recombinant human insulin-like growth factor $I$ in healthy adults. N Eng1 J Med 317: 137-140

15. Guler HP, Schmid C, Zapf J, Froesch ER (1989) Effects of recombinant insulin-like growth factor $I$ on insulin secretion and renal function in normal human subjects. Proc Natl Acad Sci USA 86: 2868-2872

16. Froesch ER, Zapf J (1985) Insulin-like growth factors and insulin: comparative aspects. Diabetologia 28: 485-493

17. Meuli C, Froesch ER (1977) Insulin and nonsuppressible insulinlike activity (NSILA-S) stimulate the same glucose transport system via two separate receptors in rat heart. Bioch Biophys Res Commun 75: 689-695

18. Zapf J, Walter H, Froesch ER (1981) Radioimmunological determination of insulin-like growth factors I and II in normal subjects and in patients with growth disorders and extrapancreatic tumor hypoglycaemia. J Clin Invest 68: 1321-1330

19. Zapf J, Schmid C, Guler HP et al. (1990) Regulation of binding proteins for insulin-like growth factors in humans. I Clin Invest 86: 952-961

20. Poggi C, LeMarchand-Brustel Y, Zapf J, Froesch ER, Freychet P (1979) Effects and binding of insulin-like growth factor I in the isolated soleus muscle of lean and obese mice: comparison with insulin. Endocrinology 105: 723-730

21. Zapf J, Schoenle EJ, Jagars G, Sand I, Grunwald J, Froesch ER (1979) Inhibition of the action of nonsuppressible insulin-like activity on isolated rat fat cells by binding to its carrier protein. $\mathrm{J}$ Clin Invest 63: 1077-1084
22. Heding LG (1975) Radioimmunological determination of human C-peptide in serum. Diabetologia 11: 541-548

23. Polonsky KS, Given BD, Van Cauter E (1988) Twenty-four-hour profiles and pulsatile patterns of insulin secretion in normal and obese subjects. J Clin Invest 81: $442-448$

24. Goldfine ID (1987) The insulin receptor: Molecular biology and transmembrane signalling. Endocrinol Rev 8: 235-255

25. Becker AB, Roth RA (1990) Insulin receptor structure and function in normal and pathological conditions. Ann Rev Med 41:99115

26. Abe H, Molitch ME, Van Wyk JJ, Underwood LE (1983) Human growth hormone and somatomedin C suppress the spontaneous release of growth hormone in unanesthetized rats. Endocrinology 113: 1319-1324

27. Dunaif A, Segal K, Futterweit W, Dobrjansky A (1989) Profound peripheral insulin resistance, independent of obesity, in polycystic ovary syndrome. Diabetes 38: 1165-1174

28. Froesch ER, Guler HP, Schmid C, Binz K, Zapf J (1990) Therapeutic potential of insulin-like growth factor I. Trends Endocrinology 1: 254-260

Received: 2 April 1991

and in revised form: 7 June 1991

Dr.E.J.Schoenle

University Children's Hospital

Steinwiesstr. 75

CH-8032 Zürich

Switzerland 